\title{
POLICIES TO INTERNALIZE RECIPROCAL INTERNATIONAL SPILLOVERS
}

\author{
MARTIN ALTEMEYER-BARTSCHER \\ DIRK T. G. RÜBBELKE \\ EYTAN SHESHINSKI
}

CESIFO WORKING PAPER NO. 2058

CATEGORY 8: RESOURCES AND ENVIRONMENT

JULY 2007

An electronic version of the paper may be downloaded

- from the SSRN website:

- from the RePEc website:

- from the CESifo website:

www.SSRN.com

www.RePEc.org

www.CESifo-group.de 


\title{
POLICIES TO INTERNALIZE RECIPROCAL INTERNATIONAL SPILLOVERS
}

\begin{abstract}
An effective policy scheme to overcome the suboptimal low provision levels of global public goods is developed in this paper. By suggesting a decentralized approach to raise environmental public good provision levels we take account of the lack of a coercive global authority that is able to enforce efficient international environmental regulations. In our model individual regions voluntarily commence international negotiations on public good provision, which are accompanied by side-payments. These side-payments are financed by means of regional externality-correcting taxes. Side-payments and national tax rates are designed in a mutually dependent way. The decentralized scheme we recommend for approaching Pareto efficient Nash equilibria is based on the ideas of Coasean negotiations and Pigouvian taxes. As it is implementable for a wide class of Nash solutions, it is applicable to various international externality problems.
\end{abstract}

JEL Code: F35, H23.

Keywords: transfers, environmental taxation.

Martin Altemeyer-Bartscher

Chemnitz University of Technology

09107 Chemnitz

Germany

martin.altemeyer-bartscher@wirtschaft.tuchemnitz.de
Dirk T. G. Rübbelke

Chemnitz University of Technology

09107 Chemnitz

Germany

d.ruebbelke@wirtschaft.tu-chemnitz.de

Eytan Sheshinski

Hebrew University of Jerusalem

Mount Scopus

91905 Jerusalem

Israel

mseytan@mscc.huji.ac.il

July 2007

We would like to thank Daniel Lenz and Ivan Veselic' and participants of the annual congress of the CEA in 2007 for helpful comments on a previous draft of this paper. The work of Martin Altemeyer-Bartscher is financially supported by the German Science foundation (Priority Program SSP 1142). 


\section{Introduction}

Threats to the global environment have become a main issue on the political agenda of countries. Since policies to combat these threats represent global public goods, free rider incentives prevail in the international arena. Due to the absence of an international authority, which can enforce environmental regulations on a global scale and consequently helps to overcome free-rider behavior, voluntary transnational environmental agreements are considered to be most capable of generating a more efficient environmental protection level.

Most prominent examples of international environmental agreements are the Montreal Protocol which stipulates rules to protect the ozone layer and the Kyoto Protocol which contains rules for climate protection. The latter gives reasons for fierce disputes about the best way to combat global warming. This holds even more since the Kyoto Protocol expires in 2012 and a new international regulation - a post-Kyoto mechanism - has to be found.

Recently, a price-influencing international climate protection scheme has been proposed by Nordhaus (2006) as a proper successor of the quantity approach of the Kyoto type. "This is essentially a dynamic Pigovian pollution tax for a global public good" (Nordhaus (2006: 32)). An international carbon tax scheme where no international emission limits are dictated is considered to have several significant advantages over the Kyoto mechanism. This scheme could also contain side-payments in order to motivate countries to participate. ${ }^{1}$

In this paper we will elaborate Nordhaus' proposal. We will analyze how individual countries or regions could negotiate the design of an international carbon tax scheme in a decentralized way. Such decentralized bargaining is necessary, since there is no central global authority that can appoint compulsory tax rates to individual nations. In the scheme we suggest, countries offer side-payments to their opponents that are conditional on the level of the environmental tax rates implemented in the transferreceiving opponent country. For simplicity we focus on a world consisting of two

\footnotetext{
1 "Additionally, poor countries might receive transfers to encourage early participation", Nordhaus (2006: 32).
} 
regions which enter into mutual negotiations. We investigate whether our scheme could Pareto-improve the outcome in global environmental protection or even generate a Pareto-efficient result.

In line with Rübbelke and Sheshinski (2005) we analyze the effects of taxes and transfers on the level of externalities. However, our analysis differs significantly from their investigation, since ours deals with reciprocal global externalities while their analysis considers asymmetric (unilateral) international externalities with limited geographical impact. The asymmetry they consider is an element which is in some sense equivalent to the desire to redistribute in Sheshinski (2004). In Sheshinski's analysis the tax on the externality-generating good contains a uniform component (efficiency factor) and a component that varies across households and reflects an income redistribution objective (redistributive factor). In contrast to Sheshinski (2004), the asymmetry in the model suggested by Rübbelke and Sheshinski (2005) just results from an asymmetric distribution of pollution. In analyzing the asymmetric international regional problem they combine the ideas of Coase (1960) and Pigou (1932) of solving externality problems. In our investigation of global environmental problems we revive this idea of combining the ideas of Coase (1960) and Pigou (1932).

An important advantage of the mechanism is that there is no need for a central authority to regulate environmental policy. In practice there is in general a low willingness of regional governments to give away power to a central authority, see Falkinger, Hackl and Pruckner (1996). Furthermore, a simple scheme of mutual sidepayments is easy enough to be understood by local authorities. In particular, it emerges to be difficult in real word applications to determine a baseline against which countries set their environmental policy. Nordhaus (2006) points out that especially quantity limits are troublesome because of different economic growth and heterogeneous technological circumstances across regions. However, in our paper the base line of environmental policy is simply the individual rational environmental tax raised by regional decision makers. Countries' eco-tax policy is evaluated relative to its base line, so that the opponent country does only pay transfers for the internalization of transboundary externalities. 
Many solutions to the free-rider problem call for coercion in order to internalize transboundary external effects. In line with Guttman (1978, 1987), Danziger and Schnytzer (1991) as well as Guttman and Schnytzer (1992), we propose a mechanism which neither postulates any property right on pollution nor requires any negations prior to the game played. ${ }^{2}$ Local governments are free to raise eco-taxes so that the take-it-or-leave-it offer must meet an individual rationality constraint. As a distinctive feature of our paper to the existing literature we consider economies in which the efficient allocation of private goods is implemented by an eco-tax. The eco-tax revenue is then used to finance the side-payments to correct for transboundary externalities which stem from the neighbouring country. Hence, the suggested policy generates a double environmental dividend: 1) the own eco-tax corrects national market failures (externalities due to inefficiently high environmental pollution) and 2) the raised eco-tax funds induce a correction of market failures (transnational negative externalities) in the neighbouring country. By means of the tax-transfer scheme a first-best optimum can be set up.

With respect to the literature, several contributors have analysed the internalization of reciprocal externalities by means of a transfer mechanism. Oates (1972), for example, examines the problem of reciprocal externalities in the provision of local public goods arising in a federal state. He analyses the design of federal grants which achieve an efficient allocation in the federation. Buchholz and Konrad (1995) investigate the impact of strategic transfers on the private provision of public goods. Yet, the transfers they regard are of an unconditional type. Barrett (1995) suggests collecting funds from industrialized countries in order to finance greenhouse gas abatement in developing countries. Therefore, the funds are transferred in a conditional way. Barrett (1995) recommends to collect these funds by means of a matching scheme like the one suggested by Guttman $(1978,1987)$-, because this scheme reduces the industrialized countries' incentives to take a free ride. Scheffran and Pickl (2000) also analyse conditionally transferred funds. They consider Joint Implementation measures in international climate policy, where the industrialized world can invest a fraction of its budget into new power plants in the developing world, using low-emission

\footnotetext{
${ }^{2}$ Althammer and Buchholz (1993) revive the analysis by Danziger and Schnytzer (1991) and reveal the true mechanism underlying the results of the analysis by Danziger and Schnytzer (1991). Barrett (1992) emphasizes the relevance of Guttman's (matching) approach as an effective means to move us closer to a fully cooperative outcome in international climate protection.
} 
technology. Environmental technology transfer is also investigated by e.g. Stranlund (1996), Itoh and Tawada (2003) and Takarada (2005). In contrast, our paper considers monetary transfers.

Carraro and Siniscalco $(1993,1995)$ analyse transfers as a means to broaden stable coalitions in international environmental protection. In the case of symmetric countries this broadening of coalitions requires the introduction of a minimum degree of commitment. Botteon and Carraro (1997) show for the case of heterogeneous parties that transfers might help to expand coalitions even without any forms of partial commitment. Although the analysis of stable environmental coalitions is an important one, our analysis does not consider coalition formation. Instead we regard countries non-cooperatively choosing their environmental protection levels by comparing their marginal effective cost and benefits of environmental protection.

In our analysis we proceed as follows: In Section 2 we suggest a tax-transfer scheme to overcome inefficiencies and we present the features of our model. Section 3 is dedicated to the special case of a one-sided spillover. In Section 4 we extend the analysis to the case of reciprocal externalities. Finally, Section 5 concludes.

\section{The Basic Model}

\subsection{Transboundary Pollution Spillovers}

Consider the case of a reciprocal spillover effect harming country $i(i=1,2)$. Assume this effect to be a negative externality in the shape of transboundary environmental pollution. In country $i$ a representative household's production of the externality accompanies its consumption of a private good which amounts to $x_{i}$. It also consumes a second private good of the amount $y_{i}$ which is not associated with an externality. It is assumed that households behave competitively, i.e., they ignore their own effect on total pollution. Furthermore, they take the other agents' pollution levels as given. The total environmental externalities perceived in country $i$ amount to $\phi=\phi\left(X_{1}, X_{2}\right)$ where $X_{1}$ represents the total amount of the pollution-generating private good consumption in country 1 and $X_{2}$ is the respective consumption in country 2. An eco-tax in the shape of an excise tax is levied which burdens the consumption of the polluting 
commodity. $^{3}$

\subsection{The Individual Household's Maximization Problem}

The maximization problem of a representative household in country $i$ can be expressed as follows:

$$
\operatorname{Max} ! \quad u_{i}\left(x_{i}, y_{i}, \phi\right)
$$

s.t.

B

$$
\mathrm{B}\left(p+t_{i}\right) x_{i}+y_{i}=m_{i}+\tau_{i^{-}} \sigma_{i},
$$

where $m_{l}$ denotes the level of the representative household's income, $t_{i}$ denotes the excise tax rate, $\tau_{i}=t_{i} x_{i}$ stands for the tax funds raised from the representative household and $\sigma_{i}$ is the amount of tax funds $\tau_{i}$ redistributed to others, such that $\tau_{i}$ - $\sigma_{i}$ is the amount of tax funds which the representative household gets back from its government. It is assumed that the households are naive, i.e., they do not consider the effects of their behavior on $\tau_{i}$ and $\sigma_{i}$.

We obtain the following first-order conditions:

$$
\begin{aligned}
& \frac{\partial u_{i}}{\partial x_{i}}\left(x_{i}, y_{i}, \phi\right)-\lambda\left(p+t_{i}\right)=0, \\
& \frac{\partial u_{i}}{\partial y_{i}}\left(x_{i}, y_{i}, \phi\right)-\lambda=0, \\
& p x_{i}+y_{i}-m_{i}+\sigma_{i}=0 .
\end{aligned}
$$

\subsection{Take-it-or-leave-it Offer}

Regional welfare maximizing decision makers in country $i$ do not take into account

\footnotetext{
3 "In the case of reciprocal consumption externalities, the common interpretation of the Pigouvian principle calls for taxes on the externality-creating commodities" (Green and Sheshinski (1976: 798)).
} 
negative external effects they exert on neighbouring country $j(j=1,2$ and $j \neq i)$ and hence raise inefficiently low eco-taxes on the consumption of the dirty good $x_{1}$. One method of coordinating environmental policy among regions to overcome inefficiently high transnational externality production is the implementation of a system of international side-payments. We assume that each country can make a takeit-or-leave-it offer. Country $i$, for example, could offer $\left(S_{j}, t_{j}\right)$, i.e. country $i$ offers a transfer payment $S_{j}$ which is channeled to country $j$ in order to induce this country to raise its eco-tax rate $t_{j}$ to a certain level desired by $i$. Country $j$ can either accept or reject the offer. We assume that both countries can make binding commitments with respect to their transfer payment and eco-tax levels. Local governments simultaneously offer take-it-or-leave-it contracts. In doing so, each country anticipates the subject matter $\left(S_{k}, t_{k}\right)$, with $k=i, j$, of the contract offered by the opponent.

\subsection{The First-best Policy}

As a reference we examine the maximization problem of a social planner who maximizes global welfare, i.e. the sum of both countries' welfare. We suppose that a country's welfare level is equal to the sum of the welfare levels enjoyed by the individual households located in the respective country:

$$
\begin{aligned}
& \max _{X_{1}, X_{2}} W=U_{1}\left(X_{1}, \phi\right)+U_{2}\left(X_{2}, \phi\right) \\
& \text { s. t. } p\left(X_{1}+X_{2}\right)+Y_{1}+Y_{2}=M,
\end{aligned}
$$

where $M_{1}+M_{2}=M$ denotes the sum of national income $M_{1}$ in country 1 and of national income $M_{2}$ in country 2 . The first order conditions writes:

$$
\begin{aligned}
& \frac{\partial U_{1}}{\partial X_{1}}+\frac{\partial U_{1}}{\partial \phi} \frac{\partial \phi}{\partial X_{1}}+\frac{\partial U_{2}}{\partial \phi} \frac{\partial \phi}{\partial X_{1}}=\mathrm{p} \lambda \\
& \frac{\partial U_{2}}{\partial X_{2}}+\frac{\partial U_{2}}{\partial \phi} \frac{\partial \phi}{\partial X_{2}}+\frac{\partial U_{1}}{\partial \phi} \frac{\partial \phi}{\partial X_{2}}=\mathrm{p} \lambda
\end{aligned}
$$


where the third terms on the LHS of (5) and (6) respectively denote the marginal external effects of pollution. From equations (5) and (6) as well as equation (7) we obtain the Pareto-efficient tax rates:

$$
t_{1}^{f b}=\frac{\frac{\partial U_{1}}{\partial X_{1}}}{\lambda}-p=-\frac{\frac{\partial U_{1}}{\partial \phi} \frac{\partial \phi}{\partial X_{1}}+\frac{\partial U_{2}}{\partial \phi} \frac{\partial \phi}{\partial X_{1}}}{\lambda}
$$

and

$$
t_{2}^{f b}=\frac{\frac{\partial U_{2}}{\partial X_{2}}}{\lambda}-p=-\frac{\frac{\partial U_{1}}{\partial \phi} \frac{\partial \phi}{\partial X_{2}}+\frac{\partial U_{2}}{\partial \phi} \frac{\partial \phi}{\partial X_{2}}}{\lambda} .
$$

The first-best optimal eco-tax policy $\left(t_{2}^{f b}, t_{2}^{f b}\right)$ fully internalizes pollution externalities. 


\section{Unilateral Externalities}

In this section we consider the special case of a one-sided pollution spillover-effect from country 2 to country 1 . We assume that pollution is produced in both countries but it only affects welfare in country 1 , i.e. for $\phi\left(X_{1}, X_{2}\right)>0$ with $X_{1}, X_{2}>0$ it follows $\frac{\partial U_{1}}{\partial \phi}<0$ and $\frac{\partial U_{2}}{\partial \phi}=0$. One can think of the case that country 2 can easily adapt to the adverse effects of the global warming problem, while it will cause an important loss in country 1. Schelling (1992: 4-7), for example, pointed out that climate change would entail higher costs in countries with an important agriculture sector, while industrial states are less vulnerable to global warming. ${ }^{4}$ Thus, country 2 , which does not internalize consumption externalities in country 1 , has no incentives to raise a positive eco-tax on the consumption of good $X_{2}$. However, country 1 raises taxes which fully internalize the adverse effects of consumption as there are no transboundary spillover-effects.

\subsection{The Relationship between Taxes and Transfers in Country 2}

The government of country 1 intends to induce country 2 to raise an eco-tax. Therefore it offers a take-it-or-leave-it offer which fulfills the following individualrational condition:

$$
U_{2}\left(X_{2}\left(t_{2}, S_{2}\right), Y_{2}\left(t_{2}, S_{2}\right)\right)=U_{2}\left(X_{2}(0,0), Y_{2}(0,0)\right)
$$

Country 2 will accept country 1's offer if the its utility level before the tax (LHS) has to be at least as high as its welfare after implementation of the eco-tax (RHS). The utility level $U$ of a country is assumed to be simply equal to the sum of the utility levels of its households and is described by indirect utility functions as employed in

\footnotetext{
${ }^{4}$ Yet, mainly in developing countries the agricultural sector constitutes a main part of the economy and these countries are unlikely to pay positive net transfers to the developing world. "Poorer countries are probably more vulnerable to climate change than wealthier countries" (Schelling (1995: 401)). And as the IPCC (1998: 8) stresses: "Africa is the continent most vulnerable to the impacts of projected changes because widespread poverty limits adaptation capabilities."
} 
(1). After taking into account the first-order conditions of the households' decision problem (2) and (3) and the differentiation of the sum of all households' budget constraints in country 2 , which is

$$
p\left(\frac{\partial X_{2}}{\partial t_{2}}+\frac{\partial X_{2}}{\partial I_{2}} \frac{d S_{2}}{d t_{2}}\right)+\frac{\partial Y_{2}}{\partial t_{2}}+\frac{\partial Y_{2}}{\partial I_{2}} \frac{d S_{2}}{d t_{2}}=\frac{d S_{2}}{d t_{2}},
$$

we obtain after some mathematical manipulations:

$$
\frac{d S_{2}}{d t_{2}}=-\left(\frac{t_{2}}{1+t_{2} \frac{\partial X_{2}}{\partial I_{2}}}\right) \frac{\partial X_{2}}{\partial t_{2}}>0
$$

Thereby $I_{2}$ represents the country's national income. By the individual rationality constraint (9) country 1 must compensate country 2 for the loss of regional welfare induced by the eco-tax $t_{2}$. Consequently the transfer from country 1 to country 2 has to be the higher, the higher the tax in country 2 desired by country 1 .

\subsection{Country 1's Choices}

The government of country 1 intends to maximize regional welfare. It raises an ecotax rate $t_{1}$ on home consumption and induces the implementation of an eco-tax $t_{2}$ in the neighbouring country 2 by take-it-or-leave-it contract as well. The government of the transfer paying country 1 maximizes the following indirect utility function:

$$
\underset{\mathrm{t}_{1}, \mathrm{t}_{2}}{\operatorname{Max}} \quad U_{1}\left(X_{1}\left(t_{1}, S_{2}, X_{2}\right), Y_{1}\left(t_{1}, S_{2}, X_{2}\right), \phi\left(X_{1}, X_{2}\right)\right),
$$

where $\phi=\phi\left(X_{1}, X_{2}\right)$ represents the total amount of environmental externalities perceived in country 1 . 
Welfare maximization yields the tax rate $t_{1}$ chosen by the transfer-paying country's government:

$$
t_{1}=-\frac{\frac{\partial U_{1}}{\partial \phi} \frac{\partial \phi}{\partial X_{1}}}{\lambda}>0
$$

The calculation of country 1 's optimal choice of the tax rate $t_{2}$ in country 2 which it influences via its transfer payments yields:

$$
\begin{aligned}
& t_{2}=\left(\frac{1+t_{2} \frac{\partial X_{2}}{\partial I_{2}}}{1-\frac{\partial U_{1}}{\partial \phi} \frac{\partial \phi}{\partial X_{2}}} \frac{\partial X_{2}}{\partial}\right)\left(-\frac{\frac{\partial U_{1}}{\partial \phi} \frac{\partial \phi}{\partial X_{2}}}{\lambda}\right) \\
& =-\frac{\frac{\partial U_{1}}{\partial \phi} \frac{\partial \phi}{\partial X_{2}}}{\lambda} .
\end{aligned}
$$

By comparing equations (13) and (14) with the first-best optimal reference solution derived in section 2 it becomes obvious that the choices of country 1 and therefore the tax-transfer scheme yields a Pareto-efficient outcome.

\section{Reciprocal Externalities}

Let us turn to the generalized set-up of our model with reciprocal spillover effects. Here, each country's welfare is affected by pollution $\phi$ which again depends on the consumption level in both countries. Unlike the unilateral problem in Section 3, both countries will have incentives to offer a contract to their neighbour in order to influence the eco-tax policy of the opponent.

\subsection{Relationship between Taxes and Transfers in Country 2}

Country 1 makes a take-it-or-leave-it offer to country 2 . In turn, it also receives an 
offer by its opponent. In order to fulfill the individual rationality condition no country should be better off by unilaterally rejecting the offer of its opponent. We claim that country 2 will only accept to implement a tax when its utility after the tax (LHS) remains at least equal to the state before the implementation of a tax (RHS):

$$
\begin{aligned}
& U_{2}\left(X_{2}\left(t_{2}^{*}, S_{1}, S_{2}, X_{1}\right), Y_{2}\left(t_{2}^{*}, S_{1}, S_{2}, X_{1}\right), \phi_{2}\left(X_{1}, X_{2}\left(t_{2}^{*}, S_{1}, S_{2}, X_{1}\right)\right)\right)= \\
& U_{2}\left(X_{2}\left(t_{2}, S_{1}, 0, X_{1}\right), Y_{2}\left(t_{2}, S_{1}, 0, X_{1}\right), \phi_{2}\left(X_{1}, X_{2}\left(t_{2}, S_{1}, 0, X_{1}\right)\right)\right)
\end{aligned}
$$

where $S_{2}$ represents the sum of transfers received from country $1 . X_{2}$ is the equilibrium amount of the polluting good consumed in country 2 and $Y_{2}$ is the respective amount of the second private good. The LHS denotes the welfare of country 2 if it accepts country 1 's offer $\left(S_{2}, t_{2}^{*}\right)$. In case of a rejection of the offer it raises an individual rational tax $t_{2}$.

Total differentiation yields

$$
\left(\frac{\partial U_{2}}{\partial X_{2}}+\frac{\partial U_{2}}{\partial \phi_{2}} \frac{\partial \phi_{2}}{\partial X_{2}}+\frac{\partial U_{2}}{\partial \phi} \frac{\partial \phi}{\partial X_{1}} \frac{\partial X_{1}}{\partial X_{2}}\right)\left(\frac{\partial X_{2}}{\partial t_{2}^{*}}+\frac{\partial X_{2}}{\partial I_{2}} \frac{d S_{2}}{d t_{2}^{*}}\right)+\frac{\partial U_{2}}{\partial Y_{2}}\left(\frac{\partial Y_{2}}{\partial t_{2}^{*}}+\frac{\partial Y_{2}}{\partial I_{2}} \frac{d S_{2}}{d t_{2}^{*}}\right)=0
$$

where $I_{2}$ is the net income in country 2 . When we take account of conditions (2) and (3) and the differentiation of the sum of all households' budget constraints we can also write:

$$
\left(t_{2}+\frac{\frac{\partial U_{2}}{\partial \phi_{2}} \frac{\partial \phi_{2}}{\partial X_{2}}}{\lambda}+\frac{\frac{\partial U_{2}}{\partial \phi} \frac{\partial \phi}{\partial X_{1}}}{\lambda} \frac{\partial X_{1}}{\partial X_{2}}\right)\left(\frac{\partial X_{2}}{\partial t_{2}}+\frac{\partial X_{2}}{\partial I_{2}} \frac{d S_{2}}{d t_{2}}\right)+\frac{\partial S_{2}}{\partial t_{2}}=0
$$

Rearranging terms yields: 


$$
\frac{\partial S_{2}}{\partial t_{2}}=-\frac{\left(t_{2}+\frac{\frac{\partial U_{2}}{\partial \phi} \frac{\partial \phi}{\partial X_{2}}}{\lambda}+\frac{\frac{\partial U_{2}}{\partial \phi} \frac{\partial \phi}{\partial X_{1}}}{\lambda} \frac{\partial X_{1}}{\partial X_{2}}\right) \frac{\partial X_{2}}{\partial t_{2}}}{\left[1+\left(t_{2}+\frac{\frac{\partial U_{2}}{\partial \phi} \frac{\partial \phi}{\partial X_{2}}}{\lambda}+\frac{\frac{\partial U_{2}}{\partial \phi} \frac{\partial \phi}{\partial X_{1}}}{\lambda} \frac{\partial X_{1}}{\partial X_{2}}\right) \frac{\partial X_{2}}{\partial I_{2}}\right]}
$$

The amount of money which country 1 must at least pay to country 2 is uniquely determined by the choice of the tax rate $t_{2}$. In particular, $S_{2}$ is an increasing function of $t_{2}$ for all $t_{2}<t_{2}^{*}$. Reciprocally, we can derive the marginal impact of $t_{1}$ on $S_{1}$.

\subsection{Transfer-paying Country 1's Maximization Problem}

Countries 1 and 2, both intend to maximize national welfare. Counties 1 and 2 make a take-it-or-leave-it offer $\left(S_{2}, t_{2}\right)$ and $\left(S_{1}, t_{1}\right)$, respectively. In the simultaneous move game country 1 can correctly anticipate $\left(S_{1}, t_{1}\right)$ offered by country 2 and vice versa. In the equilibrium both countries will accept the offers of their opponents respectively and we can restrict our analysis to the following maximization problem:

$$
\underset{t_{2}}{\operatorname{Max} !} \quad U_{1}\left(X_{1}\left(t_{1}, S_{1}, S_{2}, X_{2}\right), Y_{1}\left(t_{1}, S_{1}, S_{2}, X_{2}\right), \phi_{1}\left(X_{1}, X_{2}\right)\right)
$$

Maximization yields

$$
\begin{gathered}
\frac{\partial U_{1}}{\partial X_{1}}\left[\frac{\partial X_{1}}{\partial I_{2}} \frac{d S_{2}}{d t_{2}}+\frac{\partial X_{1}}{\partial X_{2}}\left(\frac{\partial X_{2}}{\partial t_{2}}+\frac{\partial X_{2}}{\partial I_{2}} \frac{d S_{2}}{d t_{2}}\right)\right]+\frac{\partial U_{1}}{\partial Y_{1}}\left[\frac{\partial Y_{1}}{\partial I_{2}} \frac{d S_{2}}{d t_{2}}+\frac{\partial Y_{1}}{\partial X_{2}}\left(\frac{\partial X_{2}}{\partial t_{2}}+\frac{\partial X_{2}}{\partial I_{2}} \frac{d S_{2}}{d t_{2}}\right)\right]+ \\
\frac{\partial U_{1}}{\partial \phi} \frac{\partial \phi}{\partial X_{1}}\left[\frac{\partial X_{1}}{\partial I_{2}} \frac{d S_{2}}{d t_{2}}+\frac{\partial X_{1}}{\partial X_{2}}\left(\frac{\partial X_{2}}{\partial t_{2}}+\frac{\partial X_{2}}{\partial I_{2}} \frac{d S_{2}}{d t_{2}}\right)\right]+\frac{\partial U_{1}}{\partial \phi} \frac{\partial \phi}{\partial X_{2}}\left[\frac{\partial X_{2}}{\partial t_{2}}+\frac{\partial X_{2}}{\partial I_{2}} \frac{d S_{2}}{d t_{2}}\right] .
\end{gathered}
$$

In order to derive country 1's optimal choice of $t_{2}$, we insert (7) and (8) aggregated 
over all households in country 1 and the derivative of the budget constraint for $t_{2}$, which is $p \frac{\partial X_{1}}{\partial t_{2}}+\frac{\partial Y_{1}}{\partial t_{2}}=-\frac{\partial S_{2}}{\partial t_{2}}$, into (19). Then we obtain

$$
\left(t_{1} \frac{\partial X_{1}}{\partial X_{2}}+\frac{\frac{\partial U_{1}}{\partial \phi} \frac{\partial \phi}{\partial X_{1}}}{\lambda} \frac{\partial X_{1}}{\partial t_{2}}+\frac{\frac{\partial U_{1}}{\partial \phi} \frac{\partial \phi}{\partial X_{2}}}{\lambda}\right)\left(\frac{\partial X_{2}}{\partial t_{2}}+\frac{\partial X_{2}}{\partial I_{2}} \frac{d S_{2}}{d t_{2}}\right)=\frac{\partial S_{2}}{\partial t_{2}}
$$

Country 2 in turn counterbids a contract to 1 so that we can write the following system of equations:

$$
\begin{aligned}
& \frac{\partial S_{2}}{\partial t_{2}}\left[1-\left(t_{1} \frac{\partial X_{1}}{\partial X_{2}}+\frac{\frac{\partial U_{1}}{\partial \phi} \frac{\partial \phi}{\partial X_{1}}}{\lambda} \frac{\partial X_{1}}{\partial X_{2}}+\frac{\frac{\partial U_{1}}{\partial \phi} \frac{\partial \phi}{\partial X_{2}}}{\lambda}\right) \frac{\partial X_{2}}{\partial I_{2}}\right]=\left(t_{1} \frac{\partial X_{1}}{\partial X_{2}}+\frac{\frac{\partial U_{1}}{\partial \phi} \frac{\partial \phi}{\partial X_{1}}}{\lambda} \frac{\partial X_{1}}{\partial X_{2}}+\frac{\frac{\partial U_{1}}{\partial \phi} \frac{\partial \phi}{\partial X_{2}}}{\lambda}\right) \frac{\partial X_{2}}{\partial t_{2}} \\
& \frac{\partial S_{1}}{\partial t_{1}}\left[1-\left(t_{2} \frac{\partial X_{2}}{\partial X_{1}}+\frac{\frac{\partial U_{2}}{\partial \phi} \frac{\partial \phi}{\partial X_{2}}}{\lambda} \frac{\partial X_{2}}{\partial X_{1}}+\frac{\frac{\partial U_{2}}{\partial \phi} \frac{\partial \phi}{\partial X_{1}}}{\lambda}\right) \frac{\partial X_{1}}{\partial I_{1}}\right]=\left(t_{2} \frac{\partial X_{2}}{\partial X_{1}}+\frac{\frac{\partial U_{2}}{\partial \phi} \frac{\partial \phi}{\partial X_{2}}}{\lambda} \frac{\partial X_{2}}{\partial X_{1}}+\frac{\frac{\partial U_{2}}{\partial \phi} \frac{\partial \phi}{\partial X_{1}}}{\lambda}\right) \frac{\partial X_{1}}{\partial t_{1}}
\end{aligned}
$$

Inserting equation (16) the equivalent marginal effect for country 1 into the system of equations (21) shows that the two countries with reciprocal spillover-effects can coordinate to play a first-best optimal eco-tax policy by a system of take-it-or-leave-it offers:

$$
\begin{array}{r}
t_{1}^{*}=\frac{\frac{\partial U_{1}}{\partial \phi} \frac{\partial \phi}{\partial X_{1}}}{\lambda}+\frac{\frac{\partial U_{2}}{\partial \phi} \frac{\partial \phi}{\partial X_{1}}}{\lambda} \\
t_{2}{ }^{*}=\frac{\frac{\partial U_{2}}{\partial \phi} \frac{\partial \phi}{\partial X_{2}}}{\lambda}+\frac{\frac{\partial U_{1}}{\partial \phi} \frac{\partial \phi}{\partial X_{2}}}{\lambda}
\end{array}
$$




\section{Concluding Remarks}

Contemporarily, in the climate protection debate several different schemes are suggested to become successors of the current Kyoto scheme. Many proposals are based on a quantity approach, i.e. the targets of these schemes are certain levels for greenhouse gas abatement (e.g., 50\%-emission reduction until 2050). In contrast, price approaches intend to raise the effective price of pollution, e.g. by levying carbon taxes world-wide. In this paper we focus on the analysis of the latter.

We examine a take-it-or-leave-it mechanism to combat global environmental externalities. Countries offer a contract to neighbouring countries to influence these countries' eco-tax policies. The contract includes the pledge to pay an income transfer to the neighbouring countries provided that these countries raise their eco-tax levels up to a level desired by the transfer-offering countries.

Welfare losses which may go along with an increase of eco-tax rates are compensated by the side-payments offered in the contracts. As a distinctive feature of our paper to the existing literature we propose a mechanism in which side-payments are financed by the revenue raised by means of the eco-taxes. Therefore there exists a double environmental dividend of these eco-taxes. On the one hand global externalities are corrected by means of the Pigouvian tax within the tax-raising country and on the other hand the respective tax revenue can be used for side-payments inducing other countries to further mitigate global environmental pollution. 
We show that in a simultaneous move game with two countries both players will offer a take-it-or-leave-it contract that entails a side-payment which meets the individual rationality constraint of the opponent player in combination with the first-best optimal tax policy. Therefore the suggested tax-transfer scheme represents an effective means to induce a global carbon-tax scheme. The scheme does not require the coercive power of a central global authority but carbon taxes are implemented voluntarily by the individual countries. 


\section{References}

Althammer, W. and Buchholz, W. (1993): Lindahl-equilibria as the Outcome of a Non-cooperative Game. European Journal of Political Economy, Vol. 9, 229-405.

Barrett, S. (1992): Convention on Climate Change - Economic Aspects of Negotiations, OECD, Paris.

Barrett, S. (1995): The Strategy of Joint Implementation in the Framework Convention on Climate Change. UNCTAD/GID/10, United Nations, New York.

Botteon, M. and Carraro, C. (1997): Burden Sharing and Coalition Stability in Environmental Negotiations with Asymmetric Countries. In: Carraro, C. (ed.), International Environmental Negotiations: Strategic Policy Issues, Edward Elgar, Cheltenham, Northampton, 26-55.

Buchholz, W. and Konrad, K.A. (1995): Strategic Transfers and Private Provision of Public Goods. Journal of Public Economics, Vol. 57, 489-505.

Carraro, C. and Siniscalco, D. (1993): Strategies for the International Protection of the Environment. Journal of Public Economics, Vol. 52, 309-328.

Carraro, C. and Siniscalco, D. (1995): Policy Coordination for Sustainability: Commitments, Transfers, and Linked Negotiations. In: Goldin, I. and Winters, L.A. (eds.), The Economics of Sustainable Development, Cambridge University Press, Cambridge et al., 264-282.

Coase, R. (1960): The Problem of Social Cost. Journal of Law and Economics, Vol. $3,1-44$.

Danziger, L. and Schnytzer, A. (1991): Implementing the Lindahl Voluntaryexchange Mechanism. European Journal of Political Economy, Vol. 7, 55-64.

Falkinger, J. F. Hackl and G.J. Pruckner (1996): A Fair Mechanism of Efficient Reduction of $\mathrm{CO}_{2}$-emmisions. Finanzarchiv, Vol. 53, 308-311.

Green, J. and Sheshinski, E. (1976): Direct versus Indirect Remedies for Externalities. Journal of Political Economy, Vol. 84, 797-808.

Guttman, J.M. (1978): Understanding Collective Action: Matching Behavior. The American Economic Review, Vol. 68, 251-255.

Guttman, J.M. (1987): A Non-Cournot Model of Voluntary Collective Action. Economica, Vol. 54, 1-19.

Guttman, J.M. and Schnytzer, A. (1992): A solution of the Externality Problem Using Strategic Matching, Journal of Economic Behaviour and Organization, Vol. 4, 249264. 
IPCC (1998): The Regional Impacts of Climate Change - An Assessment of Vulnerability. Cambridge University Press, Cambridge et al.

Itoh, A. and Tawada, M. (2003): Environment, Trade and the Welfare Gains from the Transfer of Pollution Abatement Technology. Papers in Regional Science, Vol. 82, 519-534.

Nordhaus, W.D. (2006): After Kyoto: Alternative Mechanisms to Control Global Warming. The American Economic Review, Vol. 96, 31-34.

Oates, W. E. (1972): Fiscal Federalism, Harcourt Brace Jovanovich, New York.

Pigou, A.C. (1932): The Economics of Welfare. Macmillan (London).

Rübbelke, D.T.G. and Sheshinski, E. (2005): Transfers as a Means to Combat European Spillovers. Jahrbücher für Nationalökonomie und Statistik, Vol. 225, 699710.

Scheffran, J. and Pickl, S. (2000): Control and Game-theoretic Assessment of Climatic Change: Options for Joint Implementation. Annals of Operations Research, Vol. 97, 203-212.

Schelling, T.C. (1992): Some Economics of Global Warming. The American Economic Review, Vol. 82, 1-14.

Schelling, T.C. (1995): Intergenerational Discounting. Energy Policy, Vol. 23, 395401.

Sheshinski, E. (2004): On Atmosphere Externality and Corrective Taxes. Journal of Public Economics, Vol. 88, 727-734.

Stranlund, J.K. (1996): On the Strategic Potential of Technological Aid in International Environmental Relations. Journal of Economics, Vol. 64, 1-22.

Takarada, Y. (2005): Transboundary Pollution and the Welfare Effects of Technology Transfers. Journal of Economics, Vol. 85, 251-275. 


\title{
CESifo Working Paper Series
}

\author{
(for full list see www.cesifo-group.de)
}

1996 J. Atsu Amegashie, Bazoumana Ouattara and Eric Strobl, Moral Hazard and the Composition of Transfers: Theory with an Application to Foreign Aid, May 2007

1997 Wolfgang Buchholz and Wolfgang Peters, Equal Sacrifice and Fair Burden Sharing in a Public Goods Economy, May 2007

1998 Robert S. Chirinko and Debdulal Mallick, The Fisher/Cobb-Douglas Paradox, Factor Shares, and Cointegration, May 2007

1999 Petra M. Geraats, Political Pressures and Monetary Mystique, May 2007

2000 Hartmut Egger and Udo Kreickemeier, Firm Heterogeneity and the Labour Market Effects of Trade Liberalisation, May 2007

2001 Andreas Freytag and Friedrich Schneider, Monetary Commitment, Institutional Constraints and Inflation: Empirical Evidence for OECD Countries since the 1970s, May 2007

2002 Niclas Berggren, Henrik Jordahl and Panu Poutvaara, The Looks of a Winner: Beauty, Gender, and Electoral Success, May 2007

2003 Tomer Blumkin, Yoram Margalioth and Efraim Sadka, Incorporating Affirmative Action into the Welfare State, May 2007

2004 Harrie A. A. Verbon, Migrating Football Players, Transfer Fees and Migration Controls, May 2007

2005 Helmuth Cremer, Jean-Marie Lozachmeur and Pierre Pestieau, Income Taxation of Couples and the Tax Unit Choice, May 2007

2006 Michele Moretto and Paolo M. Panteghini, Preemption, Start-Up Decisions and the Firms’ Capital Structure, May 2007

2007 Andreas Schäfer and Thomas M. Steger, Macroeconomic Consequences of Distributional Conflicts, May 2007

2008 Mikael Priks, Judiciaries in Corrupt Societies, June 2007

2009 Steinar Holden and Fredrik Wulfsberg, Downward Nominal Wage Rigidity in the OECD, June 2007

2010 Emmanuel Dhyne, Catherine Fuss, Hashem Pesaran and Patrick Sevestre, Lumpy Price Adjustments: A Microeconometric Analysis, June 2007 
2011 Paul Belleflamme and Eric Toulemonde, Negative Intra-Group Externalities in TwoSided Markets, June 2007

2012 Carlos Alós-Ferrer, Georg Kirchsteiger and Markus Walzl, On the Evolution of Market Institutions: The Platform Design Paradox, June 2007

2013 Axel Dreher and Martin Gassebner, Greasing the Wheels of Entrepreneurship? The Impact of Regulations and Corruption on Firm Entry, June 2007

2014 Dominique Demougin and Claude Fluet, Rules of Proof, Courts, and Incentives, June 2007

2015 Stefan Lachenmaier and Horst Rottmann, Effects of Innovation on Employment: A Dynamic Panel Analysis, June 2007

2016 Torsten Persson and Guido Tabellini, The Growth Effect of Democracy: Is it Heterogenous and how can it be Estimated?, June 2007

2017 Lorenz Blume, Jens Müller, Stefan Voigt and Carsten Wolf, The Economic Effects of Constitutions: Replicating - and Extending - Persson and Tabellini, June 2007

2018 Hartmut Egger and Gabriel Felbermayr, Endogenous Skill Formation and the Source Country Effects of International Labor Market Integration, June 2007

2019 Bruno Frey, Overprotected Politicians, June 2007

2020 Jan Thomas Martini, Rainer Niemann and Dirk Simons, Transfer Pricing or Formula Apportionment? Tax-Induced Distortions of Multinationals' Investment and Production Decisions, June 2007

2021 Andreas Bühn, Alexander Karmann and Friedrich Schneider, Size and Development of the Shadow Economy and of Do-it-yourself Activities in Germany, June 2007

2022 Michael Rauscher and Edward B. Barbier, Biodiversity and Geography, June 2007

2023 Gunther Schnabl, Exchange Rate Volatility and Growth in Emerging Europe and East Asia, June 2007

2024 Erkki Koskela and Ronnie Schöb, Tax Progression under Collective Wage Bargaining and Individual Effort Determination, June 2007

2025 Jay Pil Choi and Marcel Thum, The Economics of Politically Connected Firms, June 2007

2026 Jukka Pirttilä and Roope Uusitalo, Leaky Bucket in the Real World: Estimating Inequality Aversion Using Survey Data, June 2007

2027 Ruslan Lukach, Peter M. Kort and Joseph Plasmans, Strategic R\&D with Knowledge Spillovers and Endogenous Time to Complete, June 2007 
2028 Jarko Fidrmuc, Neil Foster and Johann Scharler, Labour Market Rigidities, Financial Integration and International Risk Sharing in the OECD, June 2007

2029 Bernardina Algieri and Thierry Bracke, Patterns of Current Account Adjustment Insights from Past Experience, June 2007

2030 Robert Dur and Hein Roelfsema, Social Exchange and Common Agency in Organizations, June 2007

2031 Alexander Libman and Lars P. Feld, Strategic Tax Collection and Fiscal Decentralisation: The Case of Russia, June 2007

2032 Øystein Foros, Hans Jarle Kind and Greg Shaffer, Resale Price Maintenance and Restrictions on Dominant Firm and Industry-Wide Adoption, June 2007

2033 Jan K. Brueckner and Kurt Van Dender, Atomistic Congestion Tolls at Concentrated Airports? Seeking a Unified View in the Internalization Debate, June 2007

2034 Viet Do and Ngo Van Long, International Outsourcing under Monopolistic Competition: Winners and Losers, June 2007

2035 Nadia Fiorino and Roberto Ricciuti, Determinants of Direct Democracy, June 2007

2036 Burkhard Heer and Alfred Maussner, Inflation and Output Dynamics in a Model with Labor Market Search and Capital Accumulation, June 2007

2037 Konstantinos Angelopoulos, Jim Malley and Apostolis Philippopoulos, Public Education Expenditure, Growth and Welfare, June 2007

2038 Maarten Bosker, Steven Brakman, Harry Garretsen and Marc Schramm, Adding Geography to the New Economic Geography, June 2007

2039 Steffen Henzel, Oliver Hülsewig, Eric Mayer and Timo Wollmershäuser, The Price Puzzle Revisited: Can the Cost Channel Explain a Rise in Inflation after a Monetary Policy Shock?, July 2007

2040 Rosario Crinò, Service Offshoring and White-Collar Employment, July 2007

2041 Carsten Hefeker and Michael Neugart, Labor Market Regulation and the Legal System, July 2007

2042 Bart Cockx and Muriel Dejemeppe, Is the Notification of Monitoring a Threat to the Unemployed? A Regression Discontinuity Approach, July 2007

2043 Alfons J. Weichenrieder, Profit Shifting in the EU: Evidence from Germany, July 2007

2044 Annika Alexius and Bertil Holmlund, Monetary Policy and Swedish Unemployment Fluctuations, July 2007 
2045 Axel Dreher, Jan-Egbert Sturm and Jakob de Haan, Does High Inflation Cause Central Bankers to Lose their Job? Evidence Based on a New Data Set, July 2007

2046 Guglielmo Maria Caporale and Luis A. Gil-Alana, Long Run and Cyclical Dynamics in the US Stock Market, July 2007

2047 Alessandro Balestrino, It is a Theft but not a Crime, July 2007

2048 Daniel Becker and Michael Rauscher, Fiscal Competition in Space and Time: An Endogenous-Growth Approach, July 2007

2049 Yannis M. Ioannides, Henry G. Overman, Esteban Rossi-Hansberg and Kurt Schmidheiny, The Effect of Information and Communication Technologies on Urban Structure, July 2007

2050 Hans-Werner Sinn, Please bring me the New York Times - On the European Roots of Richard Abel Musgrave, July 2007

2051 Gunther Schnabl and Christian Danne, A Role Model for China? Exchange Rate Flexibility and Monetary Policy in Japan, July 2007

2052 Joseph Plasmans, Jorge Fornero and Tomasz Michalak, A Microfounded Sectoral Model for Open Economies, July 2007

2053 Vesa Kanniainen and Panu Poutvaara, Imperfect Transmission of Tacit Knowledge and other Barriers to Entrepreneurship, July 2007

2054 Marko Koethenbuerger, Federal Tax-Transfer Policy and Intergovernmental PreCommitment, July 2007

2055 Hendrik Jürges and Kerstin Schneider, What Can Go Wrong Will Go Wrong: Birthday Effects and Early Tracking in the German School System, July 2007

2056 Bahram Pesaran and M. Hashem Pesaran, Modelling Volatilities and Conditional Correlations in Futures Markets with a Multivariate t Distribution, July 2007

2057 Walter H. Fisher and Christian Keuschnigg, Pension Reform and Labor Market Incentives, July 2007

2058 Martin Altemeyer-Bartscher, Dirk T. G. Rübbelke and Eytan Sheshinski, Policies to Internalize Reciprocal International Spillovers, July 2007 